\title{
An uncommon but important complication of renal biopsy
}

\author{
Tom Devasia, Hashir Kareem, Rajaram Prasad, Sumit Agarwal
}

Department of Cardiology, Kasturba Medical College, Manipal, Karnataka, India

\section{Correspondence to} Dr Rajaram Prasad, prasad.asaithambi@gmail.com

Accepted 11 April 2014
CrossMark

To cite: Devasia $T_{1}$ Kareem H, Prasad R, et al. BMJ Case Rep Published online: [please include Day Month Year] doi:10.1136/ bcr-2014-204925

\section{DESCRIPTION}

A 27-year-old man with stage 2 chronic kidney disease was referred for evaluation of resistant hypertension. He was on three antihypertensives including a diuretic. He was evaluated 3 years previously for uncontrolled hypertension with acute kidney injury and had undergone renal biopsy at that time. On examination, he had abdominal bruit on the left lumbar region. A renal angiography was performed which revealed a large renal arteriovenous (AV) fistula on the lower pole of the left kidney (figures 1 and 2, videos 1 and 2, respectively). He also underwent CT angiography which revealed a dilated left renal artery and lower polar artery which was tortuous with multiple saccular outpoachings. Multiple dilated venous tributaries were noted in mid pole with early opacification of

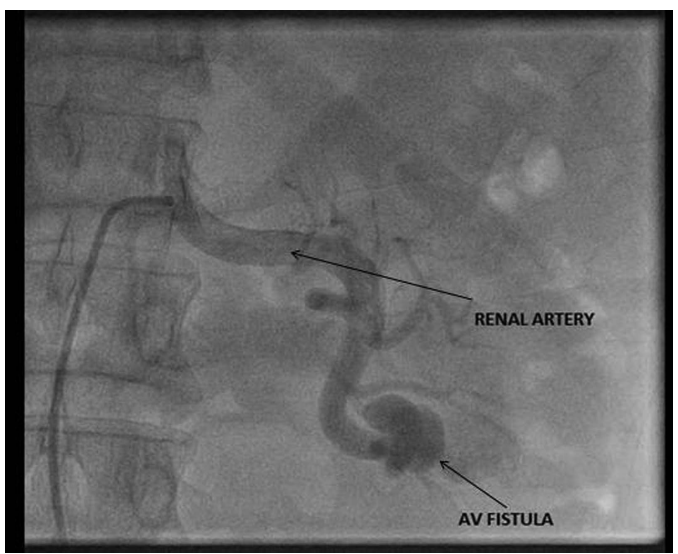

Figure 1 Selective left renal artery angiography showing the arteriovenous (AV) fistula.

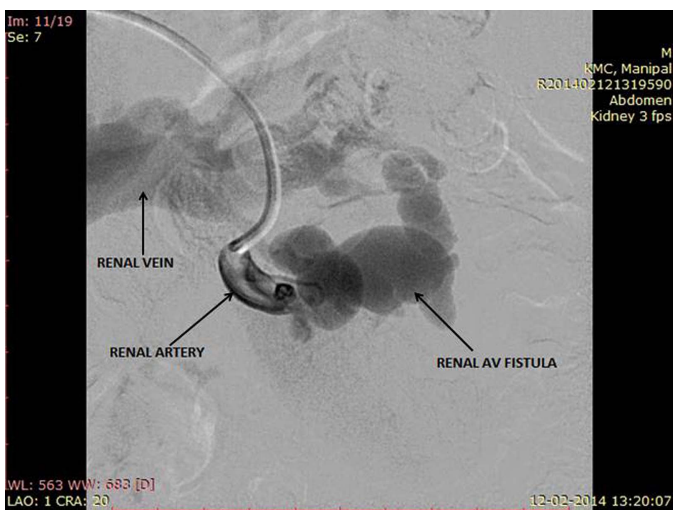

Figure 2 Subselective injection into left lower polar renal artery (digital subtraction angiogram) showing the arteriovenous (AV) fistula draining into the dilated renal vein.

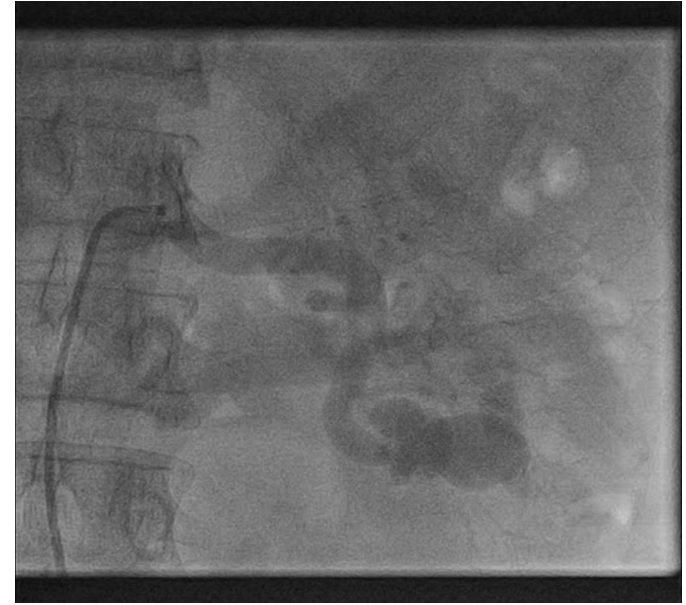

Video 1 Selective Left renal artery angiography showing the AV fistula.

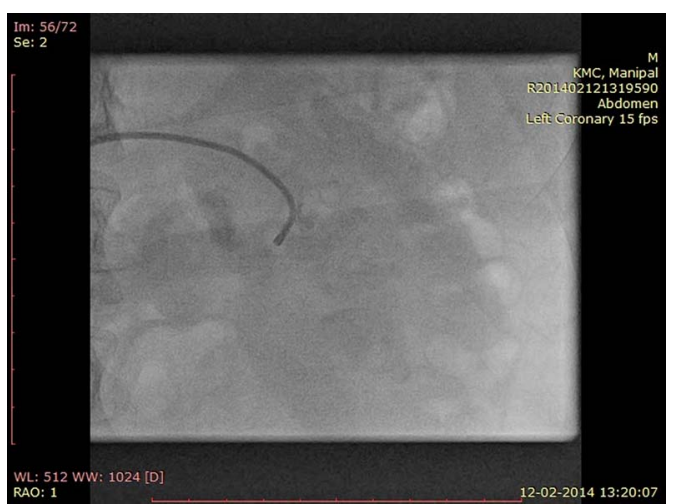

Video 2 Subselective injection in to left lower polar renal artery (digital subtraction angiogram) showing the AV fistula draining into the dilated renal vein.

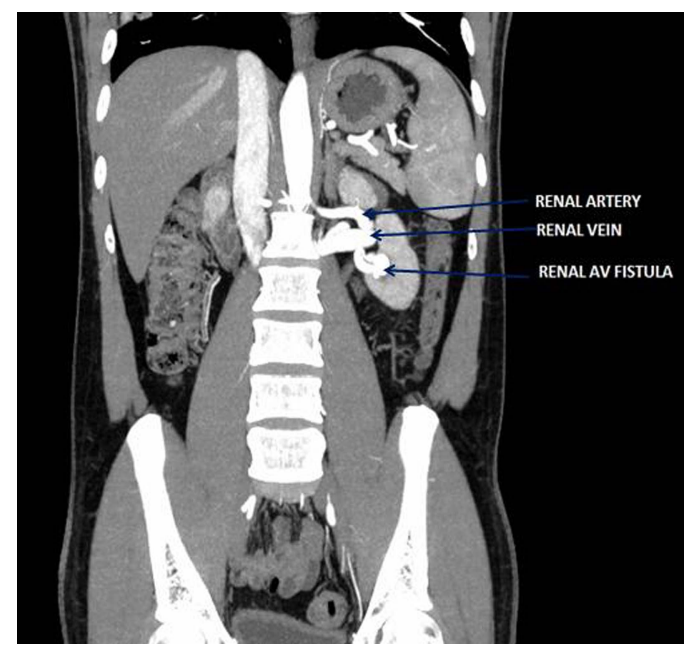

Figure 3 CT scan showing renal arteriovenous (AV) fistula. 


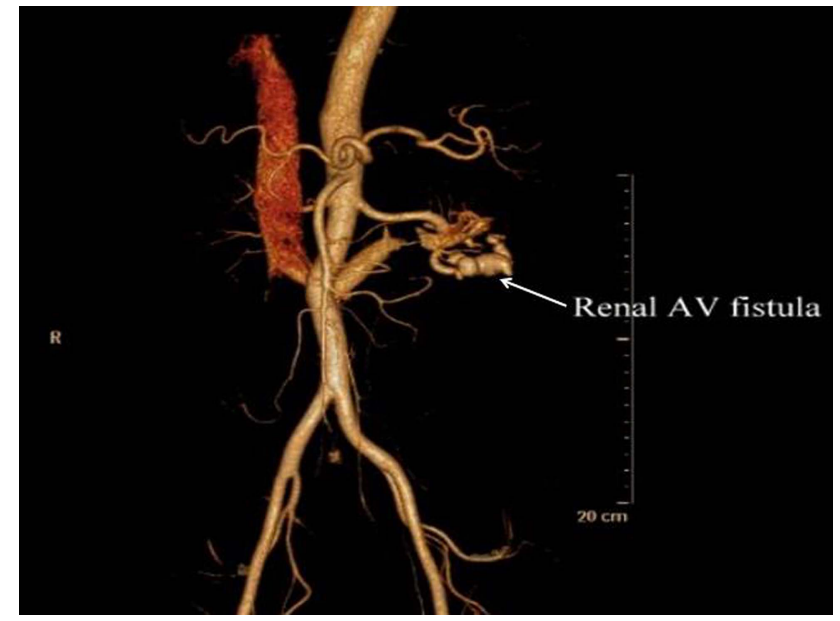

Figure 4 Three-dimensional reconstruction image of renal arteriovenous (AV) fistula.

dilated left renal vein suggestive of renal AV fistula (figures 3 and 4).

Renal AV fistula is a direct communication between the artery and vein. These vascular malformations are due to renal biopsy, trauma or percutaneous nepherectomy. There is a $5-10 \%$ incidence of AV fistula after renal biopsy. ${ }^{1}$ Majority of them $(70 \%)$ recover spontaneously in about 2 years. ${ }^{2}$ Thirty per cent do not recover and develop symptoms in the form of haematuria, hypertension, cardiac and renal failure. ${ }^{2}$ Late manifestations are hypertension, microscopic or macroscopic haematuria and worsening renal failure. Patients presenting with haematuria or worsening renal dysfunction need early intervention. Management options include partial or total nepherectomy or transcatheter selective embolisation of AV fistula with microcoils. $^{3}$ Transcatheter interventions require coil/vascular plug closure of feeding artery/arteries and the tributaries so as to prevent recurrence.

\section{Learning points}

- Renal arteriovenous fistula is an uncommon but important biopsy-related complication.

- Common presentations include resistant hypertension, haematuria and worsening renal failure.

Intervention is required if there are significant symptoms.

Competing interests None.

Patient consent Obtained.

Provenance and peer review Not commissioned; externally peer reviewed.

\section{REFERENCES}

1 Naraghi RM, Jordan ML. Surgical complications. In: Shapiro R, Simmons RL, Starzl TE eds. Renal transplantation. Stamford, CT: Appleton \& Lange, 1997:269-98.

2 Martinez T, Palmoares M, Bravo JA, et al. Biopsy induced arteriovenous fistula and venous aneurysm in renal transplant. Nephrol Dial Transplant 1998;13:2937-9.

3 LaBerge JM. Interventional management of renal transplant arteriovenous fistula. Semin Intervent Radiol 2004;21:239-46.

Copyright 2014 BMJ Publishing Group. All rights reserved. For permission to reuse any of this content visit http://group.bmi.com/group/rights-licensing/permissions.

BMJ Case Report Fellows may re-use this article for personal use and teaching without any further permission.

Become a Fellow of BMJ Case Reports today and you can:

- Submit as many cases as you like

- Enjoy fast sympathetic peer review and rapid publication of accepted articles

- Access all the published articles

- Re-use any of the published material for personal use and teaching without further permission

For information on Institutional Fellowships contact consortiasales@bmjgroup.com

Visit casereports.bmj.com for more articles like this and to become a Fellow 